Google Drive

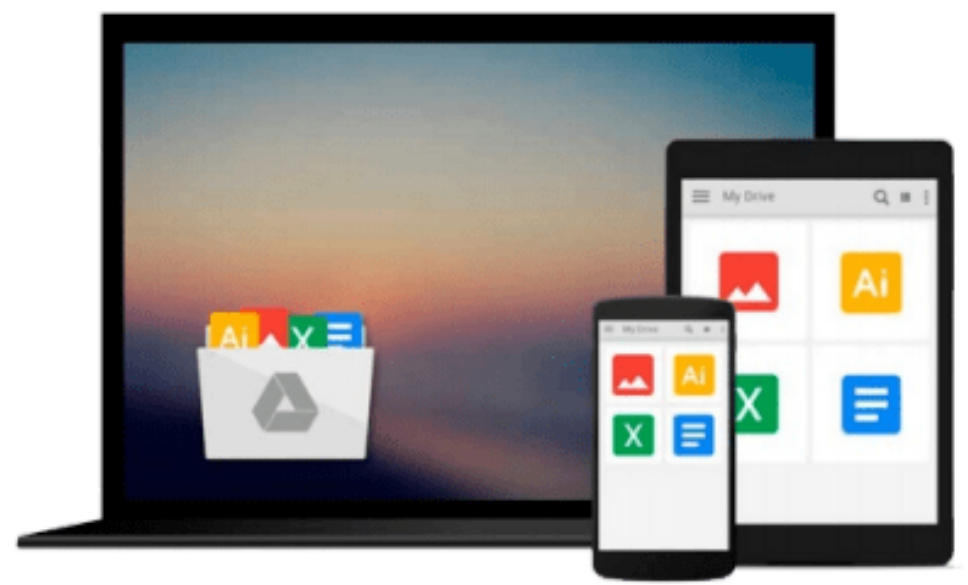

\title{
Religion, Science, and Empire: Classifying Hinduism and Islam in British India
}

Peter Gottschalk

\section{Download now}

Click here if your download doesn"t start automatically 


\title{
Religion, Science, and Empire: Classifying Hinduism and Islam in British India
}

\author{
Peter Gottschalk
}

\begin{abstract}
Religion, Science, and Empire: Classifying Hinduism and Islam in British India Peter Gottschalk Peter Gottschalk offers a compelling study of how, through the British implementation of scientific taxonomy in the subcontinent, Britons and Indians identified an inherent divide between mutually antagonistic religious communities.
\end{abstract}

England's ascent to power coincided with the rise of empirical science as an authoritative way of knowing not only the natural world, but the human one as well. The British scientific passion for classification, combined with the Christian impulse to differentiate people according to religion, led to a designation of Indians as either Hindu or Muslim according to rigidly defined criteria that paralleled classification in botanical and zoological taxonomies.

Through an historical and ethnographic study of the north Indian village of Chainpur, Gottschalk shows that the Britons' presumed categories did not necessarily reflect the Indians' concepts of their own identities, though many Indians came to embrace this scientism and gradually accepted the categories the British instituted through projects like the Census of India, the Archaeological Survey of India, and the India Museum. Today's propogators of Hindu-Muslim violence often cite scientistic formulations of difference that descend directly from the categories introduced by imperial Britain.

Religion, Science, and Empire will be a valuable resource to anyone interested in the colonial and postcolonial history of religion in India.

$\underline{\Perp}$ Download Religion, Science, and Empire: Classifying Hinduis ...pdf

E 


\section{Download and Read Free Online Religion, Science, and Empire: Classifying Hinduism and Islam in British India Peter Gottschalk}

\section{From reader reviews:}

\section{Shawn Macdonald:}

Book is to be different for every grade. Book for children right up until adult are different content. As we know that book is very important normally. The book Religion, Science, and Empire: Classifying Hinduism and Islam in British India had been making you to know about other information and of course you can take more information. It is rather advantages for you. The reserve Religion, Science, and Empire: Classifying Hinduism and Islam in British India is not only giving you more new information but also to become your friend when you truly feel bored. You can spend your own spend time to read your guide. Try to make relationship while using book Religion, Science, and Empire: Classifying Hinduism and Islam in British India. You never experience lose out for everything when you read some books.

\section{Richard Manning:}

The book untitled Religion, Science, and Empire: Classifying Hinduism and Islam in British India contain a lot of information on the idea. The writer explains your ex idea with easy approach. The language is very clear and understandable all the people, so do definitely not worry, you can easy to read it. The book was written by famous author. The author gives you in the new time of literary works. You can easily read this book because you can read on your smart phone, or product, so you can read the book throughout anywhere and anytime. If you want to buy the e-book, you can open up their official web-site and order it. Have a nice study.

\section{Casey Russell:}

This Religion, Science, and Empire: Classifying Hinduism and Islam in British India is fresh way for you who has interest to look for some information as it relief your hunger associated with. Getting deeper you into it getting knowledge more you know otherwise you who still having small amount of digest in reading this Religion, Science, and Empire: Classifying Hinduism and Islam in British India can be the light food for yourself because the information inside this kind of book is easy to get simply by anyone. These books produce itself in the form and that is reachable by anyone, that's why I mean in the e-book contact form. People who think that in publication form make them feel sleepy even dizzy this publication is the answer. So there is not any in reading a reserve especially this one. You can find what you are looking for. It should be here for an individual. So, don't miss the item! Just read this e-book style for your better life and also knowledge.

\section{Mary Adamczyk:}

You can get this Religion, Science, and Empire: Classifying Hinduism and Islam in British India by look at the bookstore or Mall. Merely viewing or reviewing it can to be your solve challenge if you get difficulties for the knowledge. Kinds of this publication are various. Not only through written or printed but additionally can you enjoy this book by means of e-book. In the modern era similar to now, you just looking from your 
mobile phone and searching what their problem. Right now, choose your current ways to get more information about your book. It is most important to arrange you to ultimately make your knowledge are still change. Let's try to choose correct ways for you.

\section{Download and Read Online Religion, Science, and Empire: Classifying Hinduism and Islam in British India Peter Gottschalk \#20ZWL5S74M6}




\section{Read Religion, Science, and Empire: Classifying Hinduism and Islam in British India by Peter Gottschalk for online ebook}

Religion, Science, and Empire: Classifying Hinduism and Islam in British India by Peter Gottschalk Free PDF d0wnl0ad, audio books, books to read, good books to read, cheap books, good books, online books, books online, book reviews epub, read books online, books to read online, online library, greatbooks to read, PDF best books to read, top books to read Religion, Science, and Empire: Classifying Hinduism and Islam in British India by Peter Gottschalk books to read online.

Online Religion, Science, and Empire: Classifying Hinduism and Islam in British India by Peter Gottschalk ebook PDF download

Religion, Science, and Empire: Classifying Hinduism and Islam in British India by Peter Gottschalk Doc

Religion, Science, and Empire: Classifying Hinduism and Islam in British India by Peter Gottschalk Mobipocket

Religion, Science, and Empire: Classifying Hinduism and Islam in British India by Peter Gottschalk EPub 